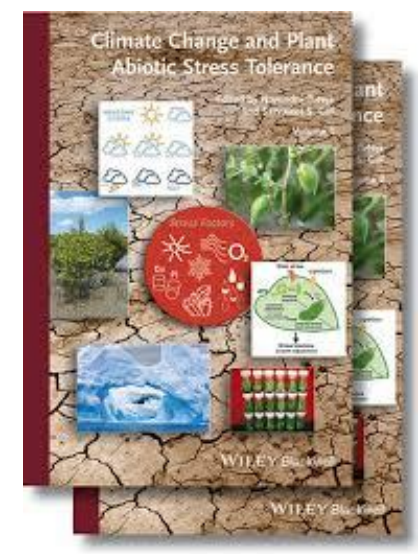

\title{
Climate Change and Heat Stress Tolerance in Chickpea
}

\author{
Pooran M. Gaur ${ }^{1}$, Aravind K. Jukanti ${ }^{2}$, Srinivasan Samineni ${ }^{1}$, Sushil K. Chaturvedi ${ }^{3}$, \\ Partha S. Basu ${ }^{3}$, Anita Babbar ${ }^{4}$, Veera Jayalakshmi ${ }^{5}$, Harsh Nayyar ${ }^{6}$, Viola \\ Devasirvatham $^{7}$, Nalini Mallikarjuna ${ }^{1}$, Laxmanan Krishnamurthy ${ }^{1}$, C.L. Laxmipathi \\ Gowda $^{1}$
}

1. International Crops Research Institute for the Semi-Arid Tropics, Grain Legumes Research Program Patancheru, Hyderabad, 502324, Andhra Pradesh, India

2. Central Arid Zone Research Institute, Division of Plant Improvement Light Industrial Area, Jodhpur, 342003, Rajasthan, India

3. Indian Institute of Pulses Research, Crop Improvement Division Kalyanpur, Kanpur, 208024, Uttar Pradesh, India

4. Jawaharlal Nehru Agricultural University, Department of Plant Breeding and Genetics, Adhartal, Jabalpur, 482004, Madhya Pradesh, India

5. Regional Agricultural Research Station, AICRP on Chickpea Noonepalli, Nandyal, 518502, Andhra Pradesh, India

6. Panjab University, Department of Botany, Sector 14, Ludhiana, 160014, Punjab, India

7. University of Sydney, Faculty of Agriculture and Environment, Australian Technology Park, Eveleigh, NSW, 2015, Australia

\section{Climate Change and Plant Abiotic Stress Tolerance}

Editor(s): Narendra Tuteja, Sarvajeet S. Gill

DOI: http://dx.doi.org/10.1002/9783527675265.ch31

This is author version post print archived in the official Institutional Repository of ICRISAT www.icrisat.org 


\section{Climate Change and Heat Stress Tolerance in Chickpea}

P.M. Gaur ${ }^{1 *}$, A.K. Jukanti ${ }^{2}$, S. Srinivasan ${ }^{1}$, S.K. Chaturvedi ${ }^{3}$, P.S. Basu ${ }^{3}$, A. Babbar ${ }^{4}$, V. Jayalakshmi $^{5}$, H. Nayyar ${ }^{6}$, V. Devasirvatham ${ }^{1,7}$, N. Mallikarjuna ${ }^{1}$, L. Krishnamurthy ${ }^{1}$ and C.L.L. Gowda ${ }^{1}$

${ }^{1}$ International Crops Research Institute for the Semi-Arid Tropics (ICRISAT)

Patancheru, Hyderabad 502 324, AP, India

${ }^{2}$ Central Arid Zone Research Institute (CAZRI), Jodhpur 342003, Rajasthan, India

${ }^{3}$ Indian Institute of Pulses Research (IIPR), Kanpur 208024, UP, India

${ }^{4}$ Jawaharlal Nehru Agricultural University, Jabalpur 482 004, MP, India

${ }^{5}$ Regional Agricultural Research Station, Nandyal 518 502, AP, India

${ }^{6}$ Panjab University, Ludhiana 160 014, India

${ }^{7}$ Faculty of Agriculture and Environment, University of Sydney, 2015, NSW, Australia

*Corresponding author, e-mail: p.gaur@cgiar.org

\subsection{Summary}

Chickpea (Cicer arietinum L.) is a cool season food legume and suffers heavy yield losses when exposed to heat stress at reproductive (flowering and podding) stage. Heat stress is increasingly becoming a severe constraint to chickpea production due to changing scenario of chickpea cultivation and expected overall increase in the global temperatures due to climate change. A temperature of $35^{\circ} \mathrm{C}$ was found to be critical in differentiating heat tolerant and sensitive genotypes in chickpea under field conditions. Large genetic variations exist in chickpea for reproductive stage heat tolerance. Many heat tolerant genotypes have been identified through screening of germplasm/breeding lines under heat stress conditions in the field. A heat tolerant breeding line ICCV 92944 has been released in two countries (as Yezin 6 in Myanmar and JG 14 in India) and is performing well under late sown conditions. Heat stress during the reproductive phase adversely affects pollen viability, fertilization, pod set and seed development leading to abscission of flowers and pods and substantial losses in grain yield. Studies on physiological mechanisms and genetics of heat tolerance and identification of molecular markers and candidate genes for heat tolerance are in progress. The information generated from these studies will help in developing effective and efficient breeding strategies for heat tolerance. The precision and efficiency of breeding programs for improving heat tolerance can be enhanced by integrating novel approaches, such as markerassisted selection, rapid generation turnover (RGT) and gametophytic selection. Chickpea cultivars with enhanced heat tolerance will minimize yield losses in cropping systems/growing conditions where the crop is exposed to heat stress at the reproductive stage.

\subsection{Introduction}

Chickpea (Cicer arietinum L.) is a cool season food legume grown in more than 50 countries across all continents. It is the second largest grown and produced pulse in the world after beans. During 2010, chickpea was grown on 12 million ha, had a production of 11 million metric tons and an average productivity of $911 \mathrm{~kg}$ per ha [1]. The major chickpea producing countries include India, Australia, Pakistan, Turkey, Myanmar, Ethiopia, Iran, Mexico, Canada and USA. India is the largest chickpea producing country with a share of $68 \%$ in the area and production of chickpea in the world. However, this production is still not sufficient 
to meet the domestic demand. As a result, India imports chickpea to bridge the gap between demand and production of chickpea in the country.

Chickpea is a good source of protein $(20-22 \%)$ and rich in carbohydrates ( $60 \%)$, dietary fibre, minerals and vitamins [2-4]. There is a growing international demand for chickpea, and the number of chickpea importing countries has increased from about 60 in 1989 to over 140 in 2009 [1]. This is partially due to increased awareness about health benefits of pulses, including chickpea. Chickpea has several potential health benefits, including beneficial effects on some of the important human diseases such as cardiovascular diseases, type 2 diabetes, digestive diseases and some forms of cancer [4].

Like other legumes, chickpea fixes atmospheric nitrogen through symbiotic nitrogen fixation and this reduces the need for chemical fertilizer, thereby lowering costs of production and associated greenhouse gas emissions. The residual nitrogen in the soil after chickpea cultivation benefits the subsequent crop. This is particularly important when the subsequent crop is a cereal. Crop diversification with legumes is highly desired in cereal dominated cropping systems for improving and sustaining the overall productivity of the cropping system.

Drought and heat are the most important constraints to chickpea production globally. It is estimated that drought and heat stresses together account for about $50 \%$ of the yield losses caused by abiotic stresses. The economic value of these losses is estimated at US\$1.28 billion [5]. Chickpea is a dry and cool season crop, largely grown rainfed on residual soil moisture after the rainy season. The progressively receding soil moisture conditions often lead to moisture stress towards end of the crop season (terminal drought) causing heavy yield losses. Development of cultivars that can escape (early maturity) or avoid/tolerate (greater extraction of water from the soil, enhanced water use efficiency) terminal drought has been a major objective in chickpea breeding program [6-10].

Exposure to heat stress $\left(\geq 35^{\circ} \mathrm{C}\right)$ at flowering and podding in chickpea is known to result in drastic reductions in seed yields [11-13]. In comparison to drought and other abiotic stresses, heat stress has received relatively less attention in chickpea breeding programs in the past. However, it has drawn considerable attention during the recent years. It is now well recognized that heat stress at the reproductive stage is increasingly becoming a serious constraint to chickpea productivity. This is because of (1) large shift in chickpea area from cooler long-season environments to warmer short-season environments, (2) increasing chickpea area under late sown conditions due to increasing cropping intensity, and (3) expected overall increase in temperatures due to climate change [9]. In India during 1964/65 to $2009 / 10$, the chickpea area reduced by 4.3 million ha (from 5.1 million ha to 0.8 million ha) in northern and northeastern India (Punjab, Haryana, Uttar Pradesh, Punjab), which has cooler long-season environments, and increased by 4.3 million ha (from 2.0 million ha to 6.3 million ha) in central and southern India (Madhya Pradesh, Maharashtra, Andhra Pradesh, Karnataka), which has relatively warmer and short-season environments (Fig 1). Thus, there has been a considerable increase in chickpea area which is prone to heat stress during reproductive development. 


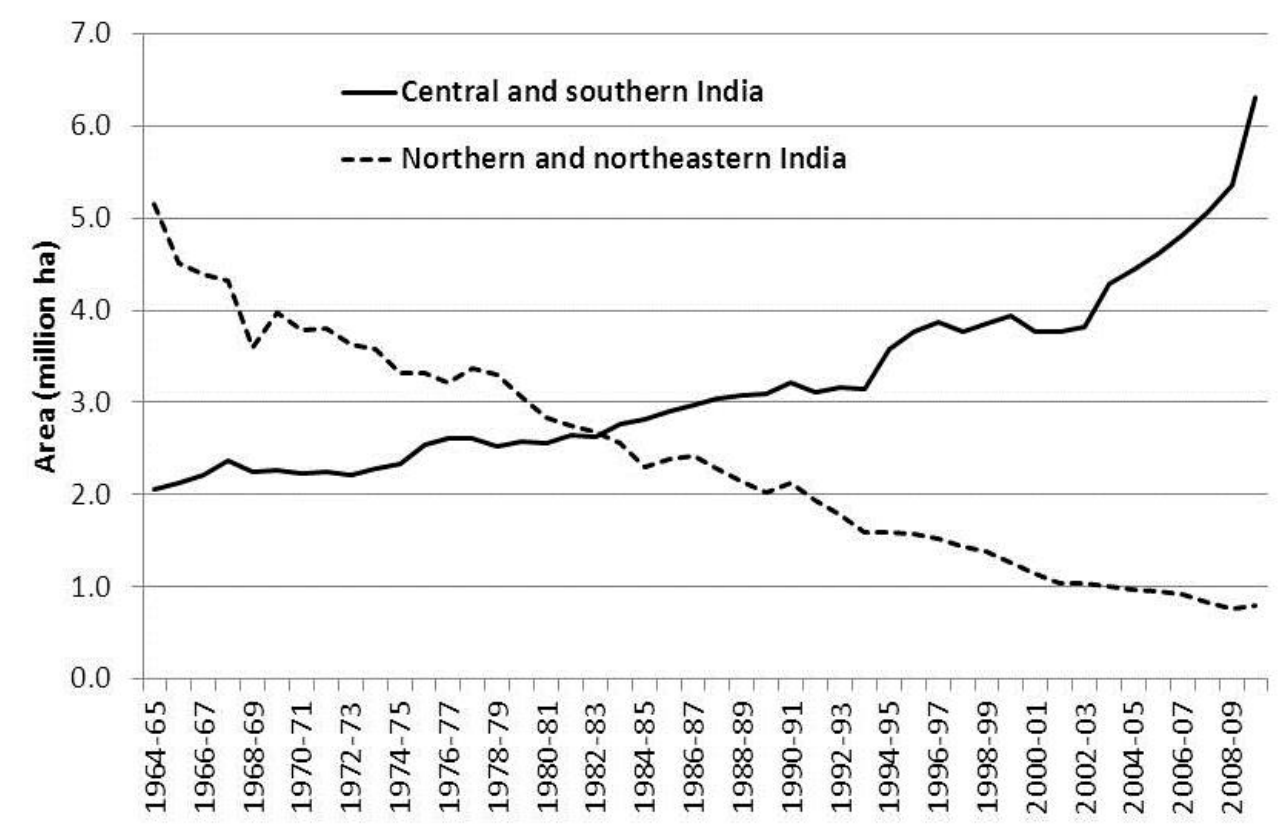

Fig 1.1: Shift in chickpea area from northern and northeastern India (cooler, longseason environments) to central and southern India (warmer, short-season environments) during 1964/65 to 2009/10.

In India, chickpea was earlier sown during late-September to late-October in most of the areas, but now there is a wide range in sowing time extending to the end of December. This is because of increasing cropping intensity and inclusion of chickpea in new cropping systems. Farmers are desperate to enhance their income and making every effort to enhance cropping intensity. Some farmers with assured irrigation facilities are taking three sequential crops in a year, e.g. a rainy-season crop, such as maize (July-Sept) followed by a short-duration vegetable crop, such as potato (Oct-Nov), which is then followed by chickpea (Dec-Apr). Irrigated chickpea in late sown conditions suffers heavy yield losses from heat stress at the reproductive stage.

Many studies on climate change have indicated that the average surface temperatures are expected to raise by $3-5^{\circ} \mathrm{C}$, posing a major threat to crop production (including legumes) and agricultural systems worldwide, especially in the semi-arid tropics $[14,15]$. Moreover, increase in temperature will have more adverse effects especially on cool-season crops (e.g. chickpea) than the rainy-season crops $[\mathbf{1 6}]$.

The optimal temperatures for chickpea growth range between $10^{\circ} \mathrm{C}$ and $30^{\circ} \mathrm{C}$ [17]. Reproductive phase (flowering and seed development) of chickpea is particularly sensitive to heat stress. A few days of exposure to high temperatures $\left(\geq 35^{\circ} \mathrm{C}\right)$ during reproductive phase can cause heavy yield losses through flower and pod abortion. Using crop growth simulation models, the effect of increasing seasonal temperature on chickpea yield in northwestern part of India was studied [18]. The models suggested a decrease in chickpea yield in all the four states (Punjab, Rajasthan, Uttar Pradesh and Haryana) with rise in seasonal temperature. Maximum decrease of $301 \mathrm{~kg} \mathrm{ha}^{-1}$ in grain yield was observed in Haryana, whereas a minimum decrease of $53 \mathrm{~kg} \mathrm{ha}^{-1}$ was observed in Uttar Pradesh per degree rise in seasonal temperature. This indicates how the heat stress is going to be a challenging issue for chickpea productivity in the future climatic conditions. 
This book chapter provides an update on the past and current research efforts on heat tolerance in chickpea and future prospects for developing heat tolerant chickpea cultivars for enhancing its resilience to impacts of climate change.

\subsection{Effect of heat stress on chickpea}

High temperatures initially affect seed germination and crop establishment. Though genotypic variation exists in chickpea for high temperature tolerance at seed germination, no germination was observed at $>45^{\circ} \mathrm{C}$ [19]. There are diverse reports on optimum temperatures for seed germination, ranging from $10-15^{\circ} \mathrm{C}$ [20] to $28-33^{\circ} \mathrm{C}$ [21]. Covell et al. [22] showed that $80 \%$ of chickpea seed germinated between 31.8 to $33.8^{\circ} \mathrm{C}$. Crop establishment in chickpea is reduced under heat stress due to its impact on important physiological processes like low photosynthetic rates and high transpiration rates [19].

Heat stress affects wide range of morphological and physiological processes, and alters plantwater relationship, ultimately affecting crop growth and development [23]. Though reduction in growth of legumes including chickpea has been reported [11, 24-26], the biological processes that are affected by heat stress are less understood in legumes compared to cereals. Heat stress-related symptoms in legumes including chickpea are: withering and burning of leaves/stems, desiccation of plants, stunting, senescence and abscission, shoot and root growth inhibition, flower and pod abortion, pod damage, and reduced yield [27-30] Reduction in shoot dry mass, relative growth rate and net assimilation has been reported in other crops under heat stress $[\mathbf{3 1}, \mathbf{3 2}]$. Root nodulation and nitrogen fixation were also affected by heat stress in chickpea [33].

Plant phenology can be modified by changing temperature and photoperiod $[11,17]$. A combination of different temperatures and photoperiods was imposed on chickpea plants to study their effect on phenology [34]. It was observed that the rate of progression towards flowering was a linear function of mean temperature. Further, there was no recordable interaction between temperature and photoperiod but, rate of progress towards flowering was increased under longer photoperiods. Chickpea flowered earlier by about a week under heat stress $\left(45 / 25^{\circ} \mathrm{C}\right)$ compared to optimal temperatures [35]. The occurrence of earlier phenology under high temperature conditions can cause a reduction in number of reproductive branches and thereby reduces seed yields $[36,37]$. Days to flowering and maturity duration are the key phenological characters that influence crop performance especially under heat stress conditions therefore, these parameters are important while breeding heat tolerant chickpea cultivars.

The most sensitive organs to heat damage in chickpea are flowers [33]. Increased reproductive organ damage $[\mathbf{2 3}, \mathbf{3 8}]$, reduced time interval for normal growth of reproductive organs $[39,40]$ and accelerated growth rate $[41,42]$ could be the major causes for yield reduction under high heat stress conditions. Heat stress could have a negative impact on floral bud development [43] and seed composition [44]. High temperature stress affects pollen viability, seed filling and results in pod abortion $[\mathbf{3 8}, \mathbf{4 5}, \mathbf{4 6}]$. Male sterility due to unviable pollen and anther indehiscence was observed in cowpea and bean under heat shock conditions $[\mathbf{4 7}, \mathbf{4 8}]$. Lower number of seeds could result due to loss of pollen or stigma viability $[38,49,50]$ and flower abortion (as in Brassica sp.; $[39,51]$ ) under heat stress conditions. 
Further, heat stress could adversely affect meiosis in both male and female organs, style and stigmatic position, number of pollen grains retained on stigmatic surface, growth of endosperm and also the fertilized embryo [52]. In chickpea, development of male (pollen/anther) and female (stigma, style and ovary) reproductive organs are most sensitive to abiotic stress [53]. High temperature has particularly detrimental effect on two stages of pollen development; meiosis in microspore mother cell and mature microspores [54-56]. Heat stress could also affect the development of tapetal cells resulting in degeneration and premature development of pollen in case of cowpea and snapbean [55, 56]. Pollen germination in chickpea is optimal at $25^{\circ} \mathrm{C}$ and germination is reduced under heat stress conditions leading to reduced fertilization $[\mathbf{5 7 , 5 8}]$. Studies indicated that heat stress in chickpea has no significant effect on number of flowers formed but decreased the number of days to flowering [59]

Studies have indicated that reproductive phase of chickpea is most sensitive to heat stress [60, 61]. Heat stress at reproductive stage affects pod fill and pod set $[\mathbf{1 1}, \mathbf{3 6}, \mathbf{4 1}]$. Heat stress during pod development reduces the yields to a greater extent compared to stress at early flowering. The decrease in yield under heat stress at pod development was about $59 \%$ and $53 \%$ in desi and kabuli types respectively. The heat stress at early flowering affected the pod production by $34 \%$ in desi and $22 \%$ in kabuli type chickpea [12]. Additionally, the heat stress also reduces the biomass yield. Though there is considerable genetic variation for heat tolerance in chickpea, most genotypes do not set pods when temperature exceeds $35^{\circ} \mathrm{C}$ [62]. A more pronounced effect of high temperature stress was observed on sink size than on the source in chickpea [12]. Heat stress on developing seeds inside the pod could result in reduced germination/emergence and loss of vigor [32].

\subsection{Screening techniques for heat tolerance}

A simple and effective field screening technique for reproductive stage heat tolerance in chickpea has been developed at ICRISAT, Patancheru. Long-term weather data was collected for ICRISAT, Patancheru research farm to identify the sowing time that would coincide the reproductive phase of the crop with high temperatures $\left(>35^{\circ} \mathrm{C}\right)$. At Patancheru, chickpea is normally sown in the month of October and harvested in January/February. The highest temperatures during reproductive phase of the crop are generally below $30^{\circ} \mathrm{C}$ (Fig 2). It was found that if chickpea is sown in the month of February, the highest temperatures would be generally above $35^{\circ} \mathrm{C}$ starting from the initiation of flowering to crop maturity (Fig 2). This will be practically a second crop at Patancheru and provide natural field screening of the crop for reproductive stage heat tolerance. Generally, one set of the test material is grown during the normal-sown condition (October) and one set during the late-sown condition (February) to compare the performance of genotypes under no heat stress and heat stress conditions. 


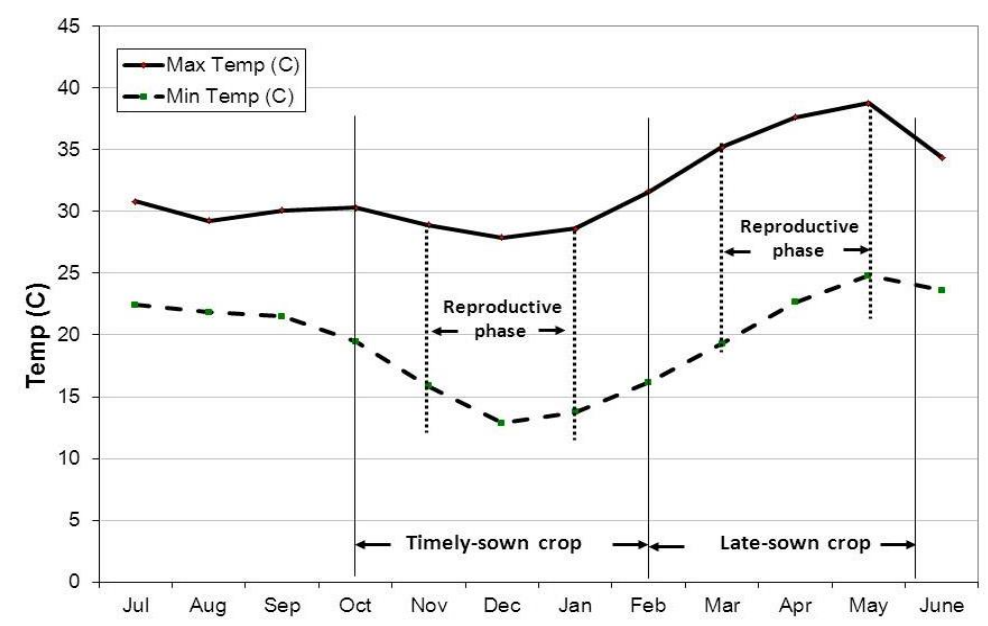

Fig 1.2: The long-term (>30 years) average temperatures for ICRISAT-Patancheru research farm. The normal chickpea crop is sown in October and the late-sown crop for heat tolerance screening is sown in February.

Though the October-sown crop can be grown on residual moisture without any supplementary irrigation, the February-sown crop has to be irrigated frequently (at 10-15 days interval). It was found that number of filled pods per plant in late-sown crop can be considered as a selection criterion for reproductive stage heat tolerance. Fig 3 shows difference in pod set between a heat sensitive line (ICC 4567) and a heat tolerant line (ICC 15614) grown under late-sown conditions at ICRISAT-Patancheru.

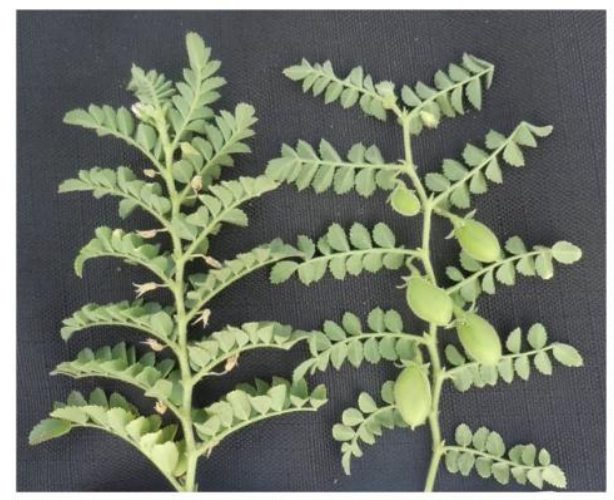

Fig 1.3: Difference in pod set between a heat sensitive line ICC 4567 (left) and a heat tolerant line ICC 15614 (right) grown under late-sown (heat stress) conditions at ICRISAT-Patancheru

As cellular membrane systems are sensitive to high temperatures, the measure of electrolyte leakage can give an indication of the extent of damage caused to cellular membranes by heat stress [63]. Studies conducted in sorghum [Sorghum bi- color (L.) Moench] suggest that the amount of electrolyte leakage from leaf segments exposed to heat shock in test tubes is an efficient means of determining cell membrane thermostability (CMT) [64]. The method is rapid, inexpensive, and requires little space, enabling heat tolerance screening of many genotypes. Electrolyte leakage has been used effectively to measure CMT in chickpea [65] and a number of other crops, including sorghum [66], groundnut [63], soybeans [67], cowpea [28], wheat [68], potato and tomato [69]. CMT has been correlated with whole-plant heat 
tolerance in some genotypes of soybean [67] and wheat [70]. However, for cowpea, electrolyte leakage of leaf disks was negatively associated with reproductive-stage heat tolerance [28]. Subsequent genetic selection experiments by Thiaw and Hall [71] confirmed that leaf electrolyte leakage under heat stress was negatively correlated with heat tolerance for pod set in cowpea.

Pollen viability test on plants exposed to heat stress at flowering can also be used for heat tolerance screening [72]. Flower buds are collected from plants exposed to high temperatures $\left(\geq 35^{\circ} \mathrm{C}\right)$ and stained with Alexander's stain and observed under a compound microscope. The viable pollen grains appear red, while the sterile pollen grains appear green. A temperature of $35^{\circ} \mathrm{C}$ was found to be critical in differentiating the heat sensitive line ICC 5912 and the heat tolerant line ICCV 92944 for pollen viability.

\subsection{Physiological mechanisms underlying heat tolerance}

Cellular membrane systems need to remain functional during heat stress, thus, maintenance of the integrity of cellular membrane systems is an important mechanism for heat tolerance in crop plants [73]. A study conducted with different legumes showed that chickpea is more sensitive to high temperatures compared to groundnut, soybean and pigeonpea, in terms of membrane stability and PS II functions [74]. However, Malhotra and Saxena [60] reported that critical temperature for heat tolerance in chickpea was higher than other legumes such as lentil, pea and faba bean. In soybean, heat stress conditions resulted in increased permeability and leakage of electrolytes, which in turn reduces photosynthetic or mitochondrial activity, and ability of plasmalemma to retain solutes and water [75]. In chickpea, membrane integrity, chlorophyll content, photochemical efficiency and cellular oxidizing ability were inhibited by the increase in temperature, with greater impacts on the sensitive genotypes [76]. Heat stress reduced cell respiration, relative leaf water content and activity of enzymes, such as Rubisco, sucrose phosphate synthase and invertase [77]. Oxidative injury as lipid peroxidation and hydrogen peroxide content was significantly greater in sensitive genotypes [76].

Exogenous application of osmoprotectants, such as proline, was found to impart partial heat tolerance in chickpea by reducing the cellular injury and protection of some vital enzymes required for carbon and oxidative metabolisms $[\mathbf{7 7}, \mathbf{7 6}]$. The role of abscisic acid (ABA) growth hormone in alleviating the heat stress in chickpea was evaluated by Kumar et al. [65]. Results indicated that exogenous application of $2.5 \mu \mathrm{M}$ ABA significantly mitigated the seedling growth at $40 / 35$ and $45 / 40^{\circ} \mathrm{C}$, while the application of fluridone (biosynthetic inhibitor of ABA) intensified the inhibition. Similarly exogenous application of osmolytes (proline, glycine betaine and trehalose) also promoted the growth in heat-stressed plants and their action was not significantly affected by fluridone.

Kumar et al. [76] found that the pollen viability, pollen germination, tube growth, pollen load and stigma receptivity decreased with increases in temperatures in chickpea. The heattolerant genotypes (ICCV 07110 and ICCV 92944) experienced significantly less damage to pollen and stigma function than the sensitive genotypes (ICC 5912 and ICC 14183). At metabolic level, the heat tolerant genotypes appeared to possess stable and more active antioxidative defence mechanism than their sensitive counterparts. Devasirvatham et al. [78] reported that the high temperatures reduced pod set in chickpea by reducing pollen viability and pollen production per flower. The pollen of heat tolerant line ICCV 92944 was viable at $35 / 20^{\circ} \mathrm{C}$ ( $41 \%$ fertile) and at $40 / 25^{\circ} \mathrm{C}$ ( $13 \%$ fertile), while the pollen of heat sensitive line ICC 5912 was completely sterile at $35 / 20^{\circ} \mathrm{C}$ with no in vitro germination and no germination on 
the stigma. However, the stigma of ICC 5912 remained receptive at $35 / 20^{\circ} \mathrm{C}$ and non-stressed pollen $\left(27 / 16^{\circ} \mathrm{C}\right)$ germinated on it during reciprocal crossing. These data indicate that pollen grains were more sensitive to high temperature than the stigma in chickpea.

High night temperature is reported to have a damaging effect on reproductive development, particularly pod and seed set, in other legumes, including common bean (Phaseolus vulgaris L.; [79]), lima bean (Phaseolus lunatus L.; [80]) and cowpea (Vigna unguiculata L.; [81]). Mutters and Hall [82] demonstrated that there is a distinct period during the 24-hr cycle when pollen development in cowpeas is sensitive to high night temperatures. The damaging effect of high night temperature on pod set was greater in long days than in short days, and red and far-red light treatments indicated that it is a phytochrome-mediated response [83]. Though it is well established that high temperatures adversely affect grain yield in chickpea, a comparison of the effects of high day temperatures and high night temperatures is yet to be made.

\subsection{Genetic variability for heat tolerance}

Until recently there were few studies on screening of chickpea germplasm for heat tolerance. Dua et al. [84] screened 25 genotypes for heat tolerance and identified two genotypes (ICCV 88512 and ICCV 88513) as heat tolerant.

The recent studies on screening of chickpea genotypes for heat tolerance indicate existence of large genotypic variation for reproductive stage heat tolerance in chickpea. Delaying the planting by two months compared to the normal in the Mediterranean climate resulted in successful identification of heat tolerant genotypes [85]. Several heat tolerant genotypes were identified from screening of 377 germplasm accessions. The kabuli types were generally more drought- and heat-susceptible than the desi types. The desi chickpea lines ACC 316 and ACC 317 exhibited tolerance to drought and heat $\left(>40^{\circ} \mathrm{C}\right)$ under field conditions. The seed size was not much affected by adverse climatic conditions and showed the highest heritability. It was suggested that days to first flowering, days to maturity, harvest index, biological yield and pods per plant should be considered ahead of other traits while breeding for heat- and drought-tolerant genotypes.

Canci and Toker [86] evaluated 68 accessions of eight annual wild Cicer species (C. bijugum, $C$. chorassanicum, C. cuneatum, $C$. echinospermum, $C$. judaicum, $C$. pinnatifidum, $C$. reticulatum and C. yamashitae) for heat (up to $41.8^{\circ} \mathrm{C}$ ) and drought tolerance and identified large genetic variability for these traits. Based on heat and drought tolerance scores, four accessions of $C$. reticulatum (AWC 605, AWC 616, AWC 620 and AWC 625) and one accession of $C$. pinnatifidum (AWC 500) were identified as promising.

A screening of 180 genotypes at Patancheru (southern India) during 2007/08 and 115 genotypes at Patancheru and Kanpur (northern India) during 2008/09 revealed large genotypic variation for heat tolerance in chickpea [87]. The genotypes that showed high heat tolerance and gave higher yields than the best known heat tolerant line ICCV 92944 over two years at Patancheru included ICCV 07104, ICCV 07105, ICCV 07110 and ICCV 07115. The genotypes that showed high levels of heat tolerance both at Kanpur and Patancheru included ICCV 07104, ICCV 07105 and IPC 2006-99.

The reference set of chickpea showed large genotypic variability for heat tolerance [88]. The reference set consists of 300 genotypes and represents genetic variability present in the 
chickpea germplasm available at ICRISAT and International Center for Agricultural Research in the Dry Areas (ICARDA) [89]. The reference set $(n=280)$, excluding 20 genotypes (accessions of wild species and very late genotypes), was evaluated under heat stress conditions at Patancheru and Kanpur. A heat tolerance index (HTI) was calculated using a multiple regression approach where grain yield under heat stress is considered as a function of yield potential and time to $50 \%$ flowering. There were large and significant variations for HTI, phenology, yield and yield components at both the locations. Based on HTI, 18 accessions (ICC 456, ICC 637, ICC 1205, ICC 3362, ICC 3761, ICC 4495, ICC 4958, ICC 4991, ICC 6279, ICC 6874, ICC 7441, ICC 8950, ICC 11944, ICC 12155, ICC 14402, ICC 14778, ICC 14815 and ICC 15618) were identified as stable tolerant. Some of these genotypes (e.g. ICC 4958 and ICC 14778) were earlier identified as drought tolerant [90], thus, these are good sources for both drought and heat tolerance. Several genotypes were heat sensitive at both the locations and the most sensitive genotypes included ICC 4567, ICC 10685, ICC 10755 and ICC 16374.

Upadhyaya et al. [91] screened 35 early maturing chickpea germplasm accessions for heat tolerance. Heat stress affected traits such as flowering duration, days to maturity, pod number, seed weight, and grain yield. For every degree raise in temperature beyond the optimum a 10-15\% yield loss among genotypes was recorded. They identified ICC 14346 to be highly tolerant to heat stress along with nine other tolerant entries (ICC 5597, ICC 5829, ICC 6121, ICC 7410, ICC 11916, ICC 13124, ICC 14284, ICC 14368, and ICC 14653).

Devasirvatham et al. [92] screened 167 chickpea genotypes for heat tolerance over two years at ICRISAT-Patancheru. The genotype ICCV 98902 had a critical temperature of $\geq 38^{\circ} \mathrm{C}$ during pod filling period and produced the highest grain yield under heat stress. In another study, it was found that the heat tolerant genotypes ICC 1205 and ICC 15614 had greater pod setting ability compared to the heat sensitive genotypes ICC 4567 and ICC 10685 when exposed to heat stress at reproductive stage under both field and controlled environmental conditions (V. Devasirvatham, unpublished results).

\subsection{Breeding strategies for heat tolerance}

The breeding efforts exclusively dedicated on developing heat tolerant chickpea cultivars have been limited. However, several breeding lines (e.g. ICCV 07104, ICCV 07105, ICCV 07108, ICCV 07109, ICCV 07110, ICCV 07115, ICCV 07117, ICCV 07118, ICCV 98902) and cultivars (JG 14, JG 16, JG 130, JAKI 9218, JGK 2, KAK 2, ICCC 37, NBEG 3, Vishal, Vaibhav) developed from the breeding material selected at ICRISAT-Patancheru were found to have good levels of tolerance to heat stress at the reproductive stage. These were basically selected for drought tolerance, but as drought and heat stresses often occur together at Patancheru, these may have also been selected for heat tolerance. Patancheru is indeed an ideal location for screening chickpea for heat tolerance because of its climatic conditions. It is located at the latitude of $17^{\circ} 36^{\prime} 10^{\prime \prime} \mathrm{N}$ and the longitude of $78^{\circ} 20^{\prime} 39^{\prime \prime} \mathrm{E}$ and has a warm and short growing season (90-100 days) for chickpea.

The effective, efficient and simple field screening technique for heat tolerance developed at ICRISAT-Patancheru and several sources of heat tolerance identified from chickpea germplasm/breeding lines have opened new opportunities for chickpea breeding for heat tolerance. ICRISAT in partnership with Indian National Agricultural Research Systems has 
initiated concerted efforts on developing heat tolerant chickpea cultivars adapted to different agroecologies.

The breeding method being used involves crossing of selected popular cultivars with heat tolerant sources. Rapid generation turnover (RGT) as suggested by Gaur et al. [93] is often used to advance the generations and accelerate the breeding process. $F_{4}$ or $F_{5}$ populations are grown under late-sown conditions for selecting heat tolerant plants based on the number of filled pods per plant. Single plant progenies are developed from the selected heat tolerant plants with desired seed quality (seed size, color and shape). The progenies are further screened for heat tolerance and also evaluated separately for resistance to key diseases, like fusarium wilt and dry root rot. The top progenies are evaluated in replicated yield trials at the research station and then short-listed progenies are further evaluated in multilocation yield trials.

Marker-assisted selection for heat tolerance can further accelerate breeding process and facilitate combining different desired traits (e.g. resistance to diseases, seed quality, etc). Excellent progress has been made in the development of genomic resources for chickpea during the past decade. The availability of large number of molecular markers, dense genetic maps, and markers associated with some desired traits, have made it possible to integrate genomics technologies into chickpea breeding programs [94]. Recombinant inbred lines are being developed from crosses between highly tolerant and highly sensitive lines for heat tolerance. These will be used to identify molecular markers linked to heat tolerance genes. Efforts will also be made to identify candidate genes for heat tolerance.

There is also a possibility of developing a pollen selection method for heat tolerance, similar to that developed for cold tolerance. Clarke and Siddique [95], at Centre for Legumes in Mediterranean Agriculture (CLIMA) in Australia, developed a pollen screening method for cold tolerance in chickpea based on in vitro germination of pollen pre-exposed to chilling temperature and used it for transferring cold tolerance from ICCV 88516 (CTS 60543) to the popular variety Amethyst. Pollen grains of ICCV 88516 were exposed to chilling temperature for three days before using them for pollination on Amethyst. Similarly, pollen from the resultant $F_{1} \mathrm{~s}$ were subjected to cold tolerance screening before their use in backcrossing to Amethyst. The pollen selected progenies were as good as the cold tolerant parent in pod setting and led to development and release of chilling tolerant cultivars Sonali and Rupali [96]. A pollen selection method for heat tolerance has been developed in cotton [97] and can be developed for chickpea. Pollen selection through heat treatment will further improve efficiency of chickpea breeding for heat tolerance.

A heat tolerant chickpea breeding line ICCV 92944 developed at ICRISAT-Patancheru has been released for cultivation in Myanmar (as Yezin 6) and India (as JG 14). Because of its heat tolerance, it was specifically released for late-sown conditions in India. JG 14 has emerged as a promising variety for late-sown conditions in India, particularly in rice-fallows where sowing is delayed due to late harvest of rice.

It is anticipated that several new heat tolerant cultivars of chickpea will be released in the coming years and provide greater choices to the farmers. The heat tolerant cultivars will further improve adaptation of chickpea to climate change and help in expanding chickpea cultivation to areas/growing conditions prone to heat stress. 


\subsection{References}

1. FAOSTAT, (2010) http://faostat.fao.org/site/567/DesktopDefault.aspx. (Accessed 24 August 2012).

2. William, P.C. and Singh, U. (1987) The Chickpea - Nutritional quality and the Evaluation of quality in Breeding Programs, in The Chickpea, (eds M.C. Saxena and K.B Singh), ICARDA, Aleppo, Syria, pp. 329-356.

3. Zia-Ul-Haq, M., Iqbal, S., Ahmad, S., Imran, M., Niaz, A., Bhanger, M.I. (2007) Nutritional and compositional study of Desi chickpea (Cicer arietinum L.) cultivars grown in Punjab, Pakistan. Food Chemistry, 105, 1357-1363.

4. Jukanti, A.K., Gaur, P.M., Gowda, C.L.L., Chibbar, R.N. (2012) Chickpea: Nutritional properties and its benefits. British Journal of Nutrition, 108, S11-S26.

5. Ryan, J.G. (1977) A global perspective on pigeonpea and chickpea sustainable production systems: present status and future potential, in Recent Advances in Pulses Research, (eds A.N. Asthana and M. Ali), Indian Institute of Pulses Research, Kanpur, India, pp. 1-31.

6. Gaur, P.M., Gowda, C.L.L., Knights, E.J., Warkentin, T.D., Acikgoz ,N., Yadav, S.S., Kumar, J. (2007a) Breeding Achievements, in Chapter 19: Chickpea Breeding and Management (eds S.S. Yadav, B. Redden, W. Chen, B. Sharma), CABI, UK, pp. 391416.

7. Gaur, P.M., Krishnamurthy, L., Kashiwagi, J. (2008a) Improving drought-avoidance root traits in chickpea (Cicer arietinum L.): Current status of research at ICRISAT. Plant Production Science, 11, 3-11.

8. Gaur, P.M., Kumar, J., Gowda, C.L.L., Pande, S., Siddique, K.H.M, Khan, T.N., Warkentin, T.D., Chaturvedi, S.K., Than, A.M., Ketema, D. (2008b) Breeding chickpea for early phenology: perspectives, progress and prospects, in Food Legumes for Nutritional Security and Sustainable Agriculture, Vol. 2 (ed M.C. Kharkwal), Indian Society of genetics and Plant Breeding, New Delhi, India, pp. 39-48.

9. Gaur, P.M., Jukanti, A.K., Srinivasan, S., Gowda, C.L.L. (2012a) Chickpea (Cicer arietinum L.), in Breeding of Field Crops (ed D.N. Bharadwaj). Agrobios (India), Jodhpur, India. ISBN No. 978-81-7754-474-9, pp. 165-194.

10. Varshney, R.K., Lekha, P., Kashiwagi, J., Gaur, P.M., Krishnamurthy, L., Hoisington, D. (2011) Genomics and physiological approaches for root trait breeding to improve drought tolerance in chickpea (Cicer arietinum L.). in Root Genomics (eds A.C. de Oliveira and R.K. Varshney), Springer Verlag, Berlin- Heidelberg-New York, pp. 233-247.

11. Summerfield, R.J., Hadley, P., Roberts, E.H., Minchin, F.R., Rawsthrone, S. (1984) Sensitivity of chickpea (Cicer arietinum L.) to hot temperatures during the reproductive period. Experimental Agriculture, 20, 77-93.

12. Wang, J., Gan, Y.T., Clarke, F., McDonald, C.L. (2006) Response of chickpea yield to high temperature stress during reproductive development. Crop Science, 46, 2171-2178.

13. Devasirvatham, V., Tan, D.K.Y., Gaur, P.M., Raju, T.N., Trethowan, R.M. (2012c) High temperature tolerance in chickpea and its implications for plant improvement. Crop and Pasture Science, 63, 419-428.

14. IPCC. (2007) Climate change 2007: The physical science basis, in Contribution of Working Group I to the Fourth Assessment Report of the Intergovernmental Panel on 
Climate Change. (eds S. Solomon, D. Qin, M. Manning, Z. Chen, M. Marquis, K.B. Averyt, M. Tignor, H.L. Miller), Geneva: IPCC Secretariat.

15. Hall, A.E. (2001) Crop responses to environment. CRC Press LLC, Boca Raton, Florida, pp.197-208.

16. Kumar, S. (2006) Climate change and crop breeding objectives in the twenty first century. Current Science, 90, 1053-1054.

17. van der Maesen, L.J.G. (1972) A monograph of the genus, with special references to the chickpea (Cicer arietinum L.) its ecology and cultivation. Mendelingen Landbouwhoge School Wageningen, The Netherlands, pp.1-341.

18. Kalra, N., Chakraborty, D., Sharma, A., Rai, H.K., Jolly, M., Chander, S., Kumar, P.R., Bhadraray, S., Barman, D., Mittal, R.B., Lal, M., Sehgal, M. (2008). Effect of temperature on yield of some winter crops in northwest India. Current Science, 94, 82-88.

19. Singh, N.H. and Dhaliwal, G.S. (1972) Effect of soil temperature on seedling emergence in different crops. Plant and Soil, 37, 441-444.

20. Ellis, R.H., Covell, S., Roberts, E.H., Summerfield, R.J. (1986) The influence of temperature on seed germination rate in grain legumes. Journal of Experimental Botany, 183, 1503-1515.

21. Singh, F. and Diwakar, B. (1995) Chickpea botany and production practices. Skill Development Series no. 16. ICRISAT Training and Fellowships Program. International Crops Research Institute for the Semi-Arid Tropics, Andhra Pradesh, India.

22. Covell, S., Ellis, R.H., Roberts, E.H., Summerfield, R.J. (1986) The influence of temperature on seed germination rate in grain legumes I. A comparison of chickpea, lentil, soybean, and cowpea at constant temperatures. Journal of Experimental Botany, 37, 705-715.

23. Paulsen, G.M. (1994) High temperature responses of crop plants, in Physiology and Determination of Crop Yield, (eds J.M. Bennett, K.J. Boote, T.R. Sinclair and G.M. Paulsen), American Society of Agronomy, Madison, WI, pp. 365-389.

24. Udomprasert, N., Li, P.H., Davis, D.V., Markhart, A.H. (1995) Root cytokinin level in relation to heat tolerance of Phaseolus acutifolius and Phaseolus vulgaris. Crop Science, 35, 486-490.

25. Nielsen, C.L. and Hall, A.E. (1985) Responses of cowpea (Vigna ungiculata (L.) Walp.) in the field to high night air temperature during flowering. II Plant responses. Field Crops Research, 10, 181-197.

26. Stanfield, B., Ormrod D.P., Fletcher, H.F. (1966) Response of peas to environment. II. Effects of temperature in controlled environment cabinets. Canadian Journal of Plant Science, 46, 195-203.

27. Vollenweider, P. and Gunthardt-Goerg, M.S. (2005) Diagnosis of abiotic and biotic stress factors using the visible symptoms in foliage. Environmental Pollution, 137, 455-465.

28. Ismail, A.M. and Hall, A.E. (1999) Reproductive-stage heat tolerance, leaf membrane thermostability and plant morphology in cowpea. Crop Science, 39, 1762-1768.

29. Guilioni, L., Wery, J., Tardieu, F. (1997) Heat stress-induced abortion of buds and flowers in pea: is sensitivity linked to organ age or to relations between reproductive organs? Annals of Botany, 80, 159-168. 
30. Saxena, N.P., Johansen, C., Sethi, S.C., Talwar, H.S., Krishnamurthy, L. (1988) Improving harvest index in chickpea through incorporation of cold tolerance. International Chickpea Newsletter, 19, 17-19.

31. Ashraf, M. and Hafeez, M. (2004) Thermo tolerance of pearl millet and maize at early growth stages: growth and nutrient relations. Biologia Plantarum, 48, 81-86.

32. Wahid, A., Gelani, S., Ashraf, M., Foolad, M.R. (2007) Heat tolerance in plants: An overview. Environmental and Experimental Botany, 61, 199-223.

33. Toker, C., Lluch, C., Tejera, N.A., Serraj, R., Siddique, K.H.M. (2007) Abiotic Stress, in Chickpea breeding and management (eds S.S. Yadav., R.J. Redden, W. Chen, B. Sharma). CAB International, Oxfordshire, UK, pp. 474-496.

34. Roberts, E.H., Hadley, P., Summerfield, R.J. (1985) Effects of temperature and photoperiod on flowering in chickpeas (Cicer arietinum L.). Annals of Botany, 55, 881892.

35. Laurie, S. and Stewart, G.R. (1993) Effects of nitrogen supply and high temperature on the growth and physiology of chickpea. Plant, Cell and Environment, 16, 609-621.

36. van Rheenen, H.H, Singh, O., Saxena, N.P. (1997) Using evaluation techniques for photoperiod and thermo-insensitivity in pulses improvement. in Recent Advantages in Pulses Research. (eds A.N. Asthana and M. Ali) Indian Society of Pulses Research and Development, IIPR, Kanpur, India, pp. 443-458.

37. Calcagno, F. and Gallo, G. (1993) Physiological and morphological basis of abiotic stressresistance in chickpea, in Breeding for stress tolerance in cool season food legumes. (eds K.B. Singh and M.C. Saxena), (ICARDA and A Wiley-Sayce Co-publishing), pp. 293-309.

38. Hall, A.E. (2004) Breeding for adaptation to drought and heat in cowpea. European Journal of Agronomy, 21, 447-454.

39. Angadi, S.V., Cutforth, H.W., Miller, P.R., McConkey, B.G., Entz, M.H., Volkmar, K., Brandt, S. (2000) Response of three Brassica speciesto high temperature injury during reproductive growth. Canadian Journal of Plant Science, 80, 693-701.

40. Entz, M.H. and Fowler, D.B. (1991) Agronomic performance of winter versus spring wheat. Agronomy Journal, 83, 527-532.

41. Gan, Y., Angadi, S.V., Cutforth, H.W., Potts, D., Angadi, V.V., McDonald. C.L. (2004) Canola and mustard response to short periods of high temperature and water stress at different developmental stages. Canadian Journal of Plant Science, 84, 697-704.

42. Savin, R. and Nicolas, M.E. (1996) Effects of short periods of drought and high temperature on grain growth and starch accumulation of two malting barley cultivars. Australian Journal of Plant Physiology, 23, 201-210.

43. Prasad, P.V.V., Boote, K.J., Allen, L.H., Thomas, J.M.G. (2002) Effects of elevated temperature and carbon dioxide on seed-set and yield of kidney bean (Phaseolus vulgaris L.). Global Change Biology, 8, 710-721.

44. Thomas, J.M.G., Boote, K.J., Allen, L.H., Gallo-Meagher, M., Davis, J.M. (2003) Elevated temperature and carbon dioxide effects on soybean seed composition and transcript abundance. Crop Science, 43, 1548-1557. 
45. Leport, L., Turner, N.C., Davies, S.L., Siddique, K.H.M. (2006) Variation in pod production and abortion among chickpea cultivars under terminal drought. European Journal of Agronomy, 24, 236-246.

46. Boote, K.J., Allen, L.H., Prasad, P.V.V. J., Baker, T., Gesch, R.W., Snyder, A.M., Pan D., Thomas. J.M.G. (2005) Elevated temperature and $\mathrm{CO}_{2}$ impacts on pollination, reproductive growth, and yield of several globally important crops. Journal of Agricultural Meteorology, (Japan) 60, 469-474.

47. Gross, Y. and Kigel, J. (1994) Differential sensitivity to high temperature of stages in the reproductive development of common bean (Phaseolus vulgaris L.). Field Crops Research, 36, 201-212.

48. Warrag, M.O.A. and Hall, A.E. (1983) Reproductive responses of cowpea to heat stress genotypic differences in tolerance to heat at flowering. Crop Science, 23, 1088-1092.

49. Davies, S.L., Turner, N.C., Siddique, K.H.M., Plummer, J.A., Leport, A. (1999) Seed growth of desi and kabuli chickpea (Cicer arietinum L.) in a short season Mediterranean type environment. Australian Journal of Experimental Agriculture, 39, 181-188.

50. Srinivasan, A., Johansen, C., Saxena, N.P. (1998) Cold tolerance during early reproductive growth of chickpea (Cicer arietinum L.): Characterization of stress and genetic variation in pod set. Field Crops Research, 57, 181-193.

51. Morrison, M.J. and Stewart, D.W. (2002) Heat stress during flowering in summer rape. Crop Science, 42, 797-803.

52. Foolad, M.R. (2005) Breeding for abiotic stress tolerances in tomato, in Abiotic Stresses: Plant Resistance Through Breeding and Molecular Approaches, (eds M. Ashraf and P.J.C. Harris), The Haworth Press Inc., New York, USA, pp. 613-684.

53. Nayyar, H., Bains, T., Kumar, S. (2005) Low temperature induced floral abortion in chickpea: relationship to abscisic acid and cryoprotectants in reproductive organs. Environmental and Experimental Botany, 53, 39-47.

54. Iwahori, S. (1965) High temperature injuries in tomato IV. Development of normal flower buds and morphological abnormalities of flower buds treated with high temperature. Journal of the Japanese Society of Horticultural Science, 34, 33-41.

55. Ahmed, F.E., Hall, A.E., DeMason, D.A. (1992) Heat injury during floral development in cowpea (Vigna unguiculata). American Journal of Botany, 79, 784-791.

56. Suzuki, K., Takeda, H., Tsukaguchi, T., Egawa, Y. (2001) Ultra structural study of degeneration of tapetum in anther of snap bean (Phaseolus vulgaris L.) under heat-stress. Sex, Plant Reproduction, 13, 293-299.

57. Prasad, P.V.V., Boote, K.J., Allen, L.H., Thomas, J.M.G. (2003) Super optimal temperatures are detrimental to Peanut (Arachis hypogaea L.) reproductive processes and yield at both ambient and elevated carbon dioxide. Global Change Biology, 9, 17751787.

58. Jaiwal, P.K., Mehta, K. (1983) The thermo sensitivity of pollen behavior in Cicer arietinum L. International Chickpea Newsletter, 9, 15.

59. Bahuguna, R. N., Shah, D., Jha, J., Pandey, S.K., Khetarpal, S. Anand A. and Pal, M. (2012) Effect of Mild Temperature Stress on Reproduction Dynamics and Yield of Chickpea (Cicer Arietinum L.). Indian Journal Plant Physiology, 17, 1-8. 
60. Malhotra, R.S. and Saxena, M.C. (1993) Screening for cold and heat tolerance in cool season food legumes, in Breeding for stress tolerance in cool season food legumes, (eds K.B. Singh and M.C. Saxena), John Wiley \& Sons, Chichester UK, pp. 227-244.

61. Singh, K.B., Malhotra, R.S., Halila, M.H., Knights, E.J., Verma, M.M. (1994) Current Status and Future Strategy in Breeding Chickpea for Resistance to Biotic and Abiotic Stresses, in Expending the Production and Use of Cool Season Food Legumes, (eds F.J. Muehlbauer and W.J. Kaiser), Klwer Academic Pub. Printed in the Netherlands, pp. 572591.

62. Basu, P.S., Ali, M., Chaturvedi, S.K. (2009) Terminal heat stress adversely affects chickpea productivity in Northern India- Strategies to improve thermo tolerance in the crop under climate change. ISPRS Archives XXXVIII-8/W3 Workshop Proceedings: Impact of Climate Change on Agriculture, pp. 189-193.

63. Talwar, H.S., Takeda, H., Yashima, S., Senboku T. (1999) Growth and photosynthetic responses of groundnut genotypes to high temperature. Crop Science, 39, 460-466.

64. Sullivan, C.Y. (1972) Mechanisms of heat and drought resistance in grain sorghum and methods of measurement, in Sorghum in the seventies, (eds N.G.P. Rao and L.R. House). Oxford \& IBH Publishing Co., New Delhi, pp. 247-264.

65. Kumar, S., Kaushal, N., Nayyar, H., Gaur, P.M. (2012a) Abscisic acid induces heat tolerance in chickpea (Cicer arietinum L.) seedlings by facilitated accumulation of osmoprotectants. Acta Physiologia Plantarum, DOI 10.1007/s11738-012-0959-1.

66. Sullivan, C.Y. and Ross, W.M. (1979) Selecting for drought and heat resistance in grain sorghum, in Stress Physiology in Crop Plants. (eds H. Mussell and R. Staple), Wiley, New York, pp. 263-281.

67. Martineau, J.R., Specht, J.E., Williams, W.H., Sullivan, C.Y. (1979) Temperature tolerance in soybeans I. Evaluation of a technique for assessing cellular membrane thermo stability. Crop Science, 19, 75-78.

68. Saadala, M.M., Shanahan, J.F., Quick, J.S. (1990) Heat tolerance in winter wheat. I. Hardening and genetic effects on membrane thermostability. Crop Science, 30, 12431247.

69. Chen, T.H.H., Shen, Z.Y., Lee, P.H. (1982) Adaptability of crop plants to high temperature stress. Crop Science, 22, 719-725.

70. Shanahan, J.F., Edwards, I.B., Quick J.S., Fenwick, J.R. (1990) Membrane thermostability and heat tolerance of spring wheat. Crop Science, 30, 247-251.

71. Thiaw, S. and Hall, A.E. (2004) Comparision of selection for either leaf-electrolyte leakage or pod set in enhancing heat tolerance and grain yield of cowpea. Field Crops Research, 86, 239-253.

72. Devasirvatham, V., Tan, D.K.Y., Trethowan, R.M., Gaur, P.M., Mallikarjuna, N. (2010) Impact of high temperature on the reproductive stage of chickpea, in Food Security from Sustainable Agriculture, Proceedings of the $15^{\text {th }}$ Australian Society of Agronomy Conference, 15-18 November 2010, Lincoln, New Zealand.

73. Raison, J.K., Berry, J.A., Armond, P.A., Pike, C.S. (1980) Membrane properties in relation to the adaptation of plants to temperature stress, in Adaptations of Plants to Water and High Temperature Stress, (eds N.C. Turner and P.J. Kramer), John Wiley \& Sons, New York, pp. 261-273. 
74. Srinivasan, A., Takeda, H., Senboku, T. (1996) Heat tolerance in food legumes as evaluated by cell membrane thermostability and chlorophyll fluorescence techniques. Euphytica, 88, $35-45$.

75. Lin, C.Y., Chen Y.M., Key, J.L. (1985) Solute leakage in soya bean seedlings under various heat shock regimes. Plant Cell Physiology, 26, 1493-1498.

76. Kumar, S., Thakur, P., Kaushal, N., Malik, J.A., Gaur, P., Nayyar, H. (2012b) Effect of varying high temperatures during reproductive growth on reproductive function, oxidative stress and seed yield in chickpea genotypes differing in heat sensitivity. Archives of Agronomy and Soil Science. DOI:10.1080/03650340.2012.683424.

77. Kaushal, N., Gupta, K., Bhandhari, K., Kumar, S., Thakur, P., Nayyar, H. (2011) Proline induces heat tolerance in chickpea (Cicer arietinum L.) plants by protecting vital enzymes of carbon and antioxidative metabolism. Physiology and Molecular Biology of Plants, 17, $203-213$.

78. Devasirvatham, V., Gaur, P.M., Mallikarjuna, N., Raju, T.N., Trethowan, R.M., Tan, D.K.Y. (2012a) Effect of high temperature on the reproductive development of chickpea genotypes under controlled environments. Functional Plant Biology (in press).

79. Nemeskéri, E., Gyo"ry, Z., Benedek, A. (1994) Effect of Hungarian growing conditions on seed quality of shelling beans, in Proceedings of the Third Congress of the European Society for Agronomy, (eds M. Borin and Sattin, M), Padova-Abano. Italy, pp.612-614.

80. Fisher, V.J. and Weaver, C.K. (1974) Flowering, pod set and pot retention of lima bean in response to night temperature, humidity, and soil moisture. Journal of American Society of Horticultural Science, 99, 448-450.

81. Hall, A.E. (1990) Breeding for heat tolerance - an approach based on whole-plant physiology. Horticultural Science, 25, 17-19.

82. Mutters, R.G. and A.E. Hall. (1992) Reproductive responses of cowpea to high temperature during different night periods. Crop Science, 32, 202-206.

83. Mutters, R.G., Hall A.E., Patel, P.N. (1989) Photoperiod and light quality effects on cowpea floral development at high temperatures. Crop Science, 29, 1501-1505.

84. Dua, R.P. (2001) Genotypic variations for low and high temperature tolerance in gram (Cicer arietinum). Indian Journal of Agricultural Sciences, 71, 561-566.

85. Canci, H. and Toker, C. (2009a) Evaluation of yield criteria for drought and heat resistance in chickpea. Journal of Agronomy and Crop Science, 195, 47-54.

86. Canci, H. and Toker. C. (2009b) Evaluation of annual wild Cicer species for drought and heat resistance under field conditions. Genetic Resources and Crop Evolution, 56, 1-6.

87. Gaur, P.M., Chaturvedi, S.K., Tripathi, S., Gowda, C.L.L., Krishnamurthy, L., Vadez, V., Mallikarjuna, N., Varshney, R.K. (2010) Improving heat tolerance in chickpea to increase its resilience to climate change, in Book of Abstracts, $5^{\text {th }}$ International Food Legumes Research Conference (IFLRC V) and $7^{\text {th }}$ European Conference on Grain legumes (AEP VII), 26-30 April 2010, Antalya, Turkey, pp. 76.

88. Krishnamurthy, L., Gaur, P.M., Basu, P.S., Chaturvedi, S.K., Tripathi, S., Vadez, V., Rathore, A., Varshney, R.K., Gowda, C.L.L. (2011) Large genetic variation for heat tolerance in the reference collection of chickpea (Cicer arietinum L.) germplasm. Plant Genetic Resources: Characterization and Utilization, 9, 59-69. 
89. Upadhyaya, H.D., Dwivedi, S.L., Baum, M., Varshney, R.K., Udupa, S.M., Gowda, C.L.L., Hoisington, D., Singh, S. (2008) Genetic structure, diversity, and allelic richness in composite collection and reference set in chickpea (Cicer arietinum L.). BMC Plant Biology, 8, 106.

90. Krishnamurthy, L., Kashiwagi, J., Gaur, P.M., Upadhyaya, H.D., Vadez, V. (2010) Sources of tolerance to terminal drought in the chickpea (Cicer arietinum L.) minicore germplasm. Field Crops Research, 119, 322-330.

91. Upadhyaya, H.D., Dronavalli, N., Gowda, C.L.L., Singh, S. (2011) Identification and evaluation of chickpea germplasm for tolerance to heat stress. Crop Science, 51, 20792094.

92. Devasirvatham, V., Tan, D.K.Y., Gaur. P.M., Raju, T.N., Trethowan, R.M. (2012b) Effects of high temperature at different developmental stages on the yield of chickpea, in 'Capturing opportunities and overcoming obstacles in Australian agronomy'. 16th Australian Agronomy Conference, Oct 14-18th 2012, University of New England, Armidale, NSW.

93. Gaur, P.M., Srinivasan, S., Gowda, C.L.L., Rao, B.V. (2007b) Rapid generation advancement in chickpea. Journal of SAT Agricultural Research, 3, 1-3.

94. Gaur, P.M., Jukanti, A.K., Varshney. R.K. (2012b) Impact of genomic technologies on chickpea breeding strategies. Agronomy, 2, 199-221.

95. Clarke, H.J. and Siddique, K.H.M. (2004) Response of chickpea genotypes to low temperature stress during reproductive development. Field Crops Research, 90, 323-334.

96. Clarke, H.J., Khan, T.N., Siddique, K.H.M. (2004) Pollen selection for chilling tolerance at hybridisation leads to improved chickpea cultivars. Euphytica, 139, 65-74.

97. Rodriguez-Garay, B, and Barrow, J.R. 1988. Pollen selection for heat tolerance in cotton. Crop Science, 28, 857-859. 


\section{Captions for figures:}

Fig 1.1: Shift in chickpea area from northern and northeastern India (cooler, long-season environments) to central and southern India (warmer, short-season environments) during $1964 / 65$ to $2009 / 10$.

Fig 1.2: The long-term (>30 years) average temperatures for ICRISAT-Patancheru research farm. The normal chickpea crop is sown in October and the late-sown crop for heat tolerance screening is sown in February.

Fig 1.3: Difference in pod set between a heat sensitive line ICC 4567 (left) and a heat tolerant line ICC 15614 (right) grown under late-sown (heat stress) conditions at ICRISATPatancheru 


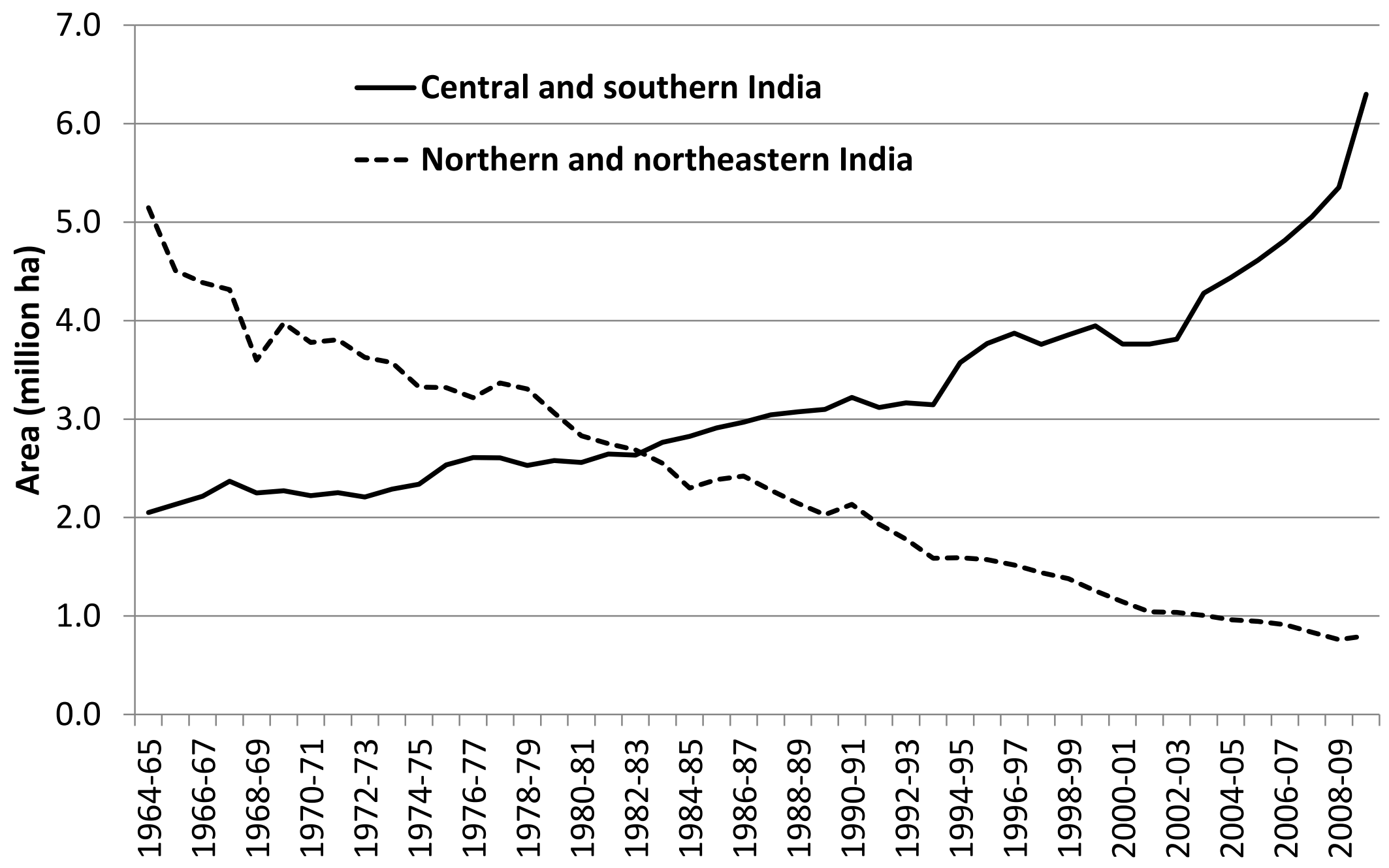




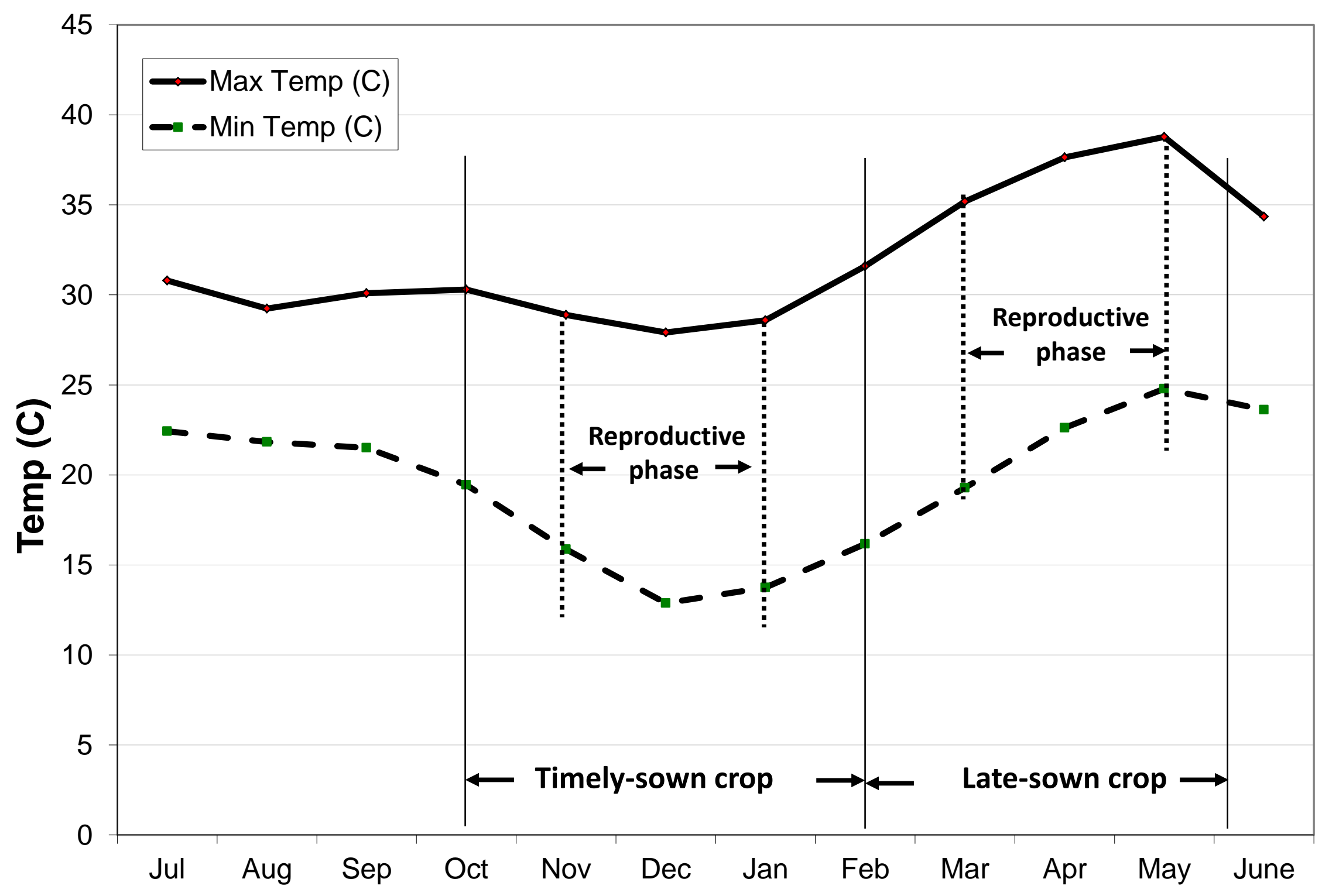




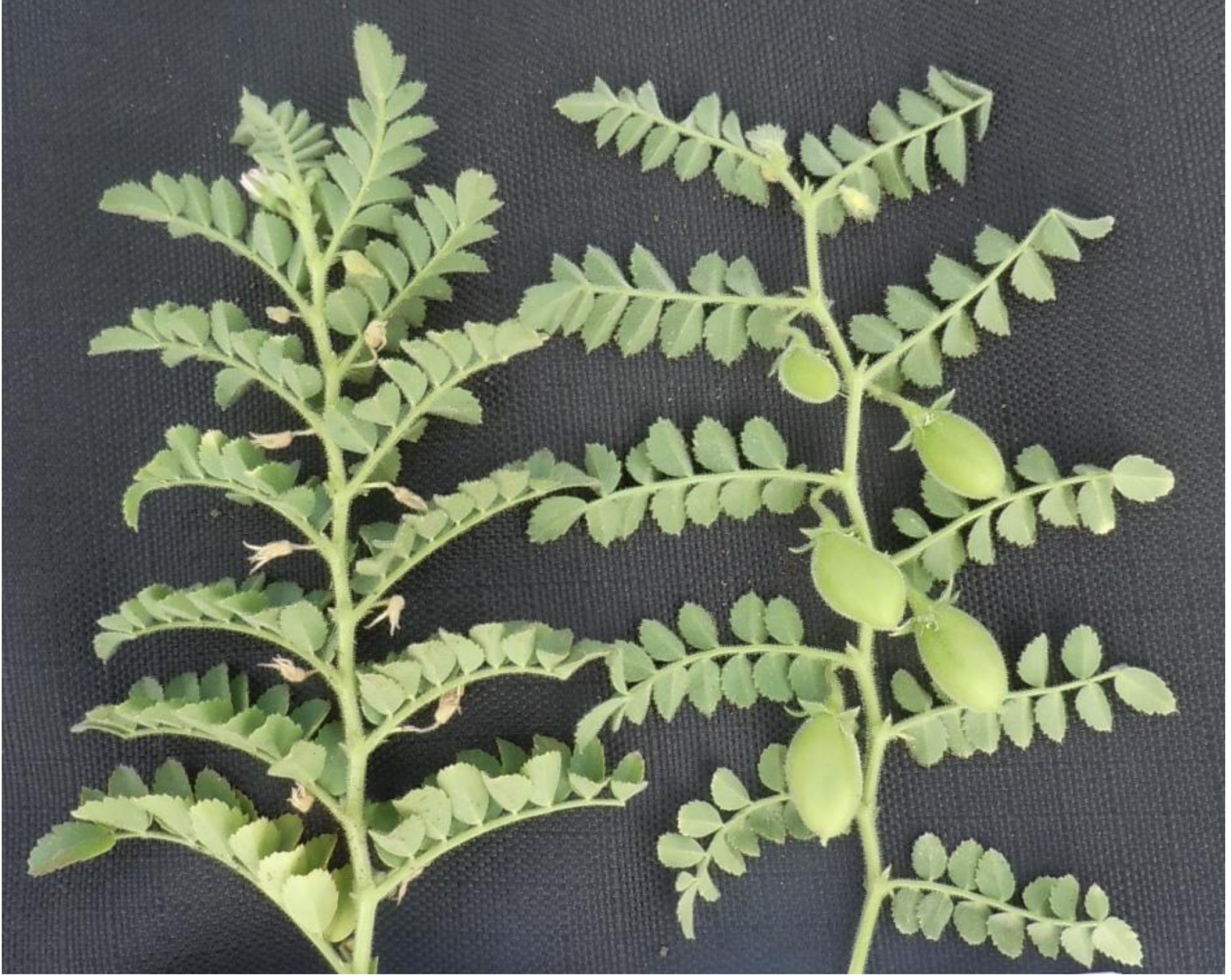

